\title{
An Endocytic Receptor, Megalin-Ligand Interactions: Effects of Glycosylation
}

\author{
Makoto Hirano \\ Department of Pharmacy, Yasuda Women's University, Hiroshima, Hiroshima 731-0153, Japan \\ FAX: +81-82-878-9540, E-mail: hirano-ma@yasuda-u.ac.jp
}

(Received on June 8, 2018, accepted on July 4, 2018)

Key Words: endocytosis, interaction, $N$-glycosylation, $L D L$ receptor-related protein

\begin{abstract}
Incorporating substances from outside across plasma membranes is an essential process for cells. Receptor-mediated endocytosis plays important roles for uptake and subsequent degradation and processing of nutrients and vitamins. Megalin is a multiligand endocytic receptor that contributes to absorption of low molecular weight proteins on the cell surface. Megalin is a $600 \mathrm{kDa}$ single-spanning transmembrane glycoprotein. It has a large extracellular domain in the N-terminus that contains four ligand-binding regions. Megalin binds with functionally and structurally distinct proteins (e.g., vitamin-binding proteins, carrier proteins and hormones) and chemical drugs (e.g., aminoglycosides) as ligands. Through the uptake of ligands, megalin mediates physiological functions in the body. Although megalin is highly glycosylated and the glycan structures have been analyzed using mass spectrometry, little has been known about the function of glycan on megalin. This article introduces the function of endocytosis mediated by megalin under physiological and pathological conditions and the effects of glycosylation of megalin on ligand-binding activity as function of glycans.
\end{abstract}

\section{A. Introduction}

Receptor-mediated endocytosis is an important cellular function for uptake of nutrients and vitamins. In polarized epithelial cells, some ligands are absorbed at one surface through the endocytic receptors and subsequently the ligands or the corresponding metabolites might be released at the opposite plasma membrane. This enables the transport of substances from one compartment to the other, known as transcytosis. Receptor-mediated endocytosis is involved in the clearance of many substances, such as nutrients, lipoproteins, and hormones, and in signaling activation by cellular uptake and subsequent degradation or transformation.

Megalin is a multi-ligand endocytic receptor and contributes to absorption of low molecular weight proteins. The receptor is expressed in epithelial cells and located in the apical membranes. Megalin is distributed not only in the kidney but also in various other tissues such as the small intestine, uterus and thyroid gland. Functionally and structurally distinct ligands of megalin have been identified, such as vitamin-binding proteins (including retinolbinding protein, RBP, and vitamin D-binding protein, DBP), carrier proteins (including albumin) and hormones (including parathyroid hormone). Through the uptake of ligands, megalin brings about physiological changes in the cells (1). Megalin has been believed to capture those ligands nonspecifically. However, a recent study demonstrated that the glycosylation of megalin modified the ligand-binding activity (2). This article focuses on the function of endocytosis through megalin and on the effects of glycosylation on the ligand-binding activity of megalin.

\section{B. Structure of Megalin}

Megalin is a $600 \mathrm{kDa}$ single-spanning type I transmembrane glycoprotein with non-glycosylated molecular weight of about $517 \mathrm{kDa}$ (4600 amino acids). Megalin is also known as low-density lipoprotein (LDL) receptor-related protein (LRP)-2 and gp330, and belongs to the LRP gene family (3). Megalin has four ligandbinding regions in the $\mathrm{N}$-terminus of the extracellular domain (4400 amino acids), a single transmembrane domain, and a small cytoplasmic tail (213 amino acids) in the C-terminus (Fig. 1) (4). The ligand-binding regions consist of cysteine-rich complementtype/LDL receptor class A repeats and are separated by 17 epidermal growth factor-like repeats and 8 cysteine-poor spacer regions. The spacer regions contain YWTD motifs involving in the $\mathrm{pH}$ dependent releasing of ligand in the endosomes (5). The cytoplasmic tail contains some motifs involved in signal transductions such as, for example, NPXY motifs, which mediate clustering in clathrin-coated pits (6).

\section{Ligands for Megalin}

Megalin binds $\mathrm{Ca}^{2+}$-dependently with functionally and structurally distinct ligands such as vitamin-binding proteins, lipoproteins, other carrier proteins, hormone and hormone precursors, enzymes, immune- and stress-response-related proteins, and some drugs (Table 1). Megalin is believed to capture these ligands nonspecifically, but no detailed studies have described its ligand specificity. In addition, few studies have been carried out to identify the ligand-specific binding regions of megalin. 


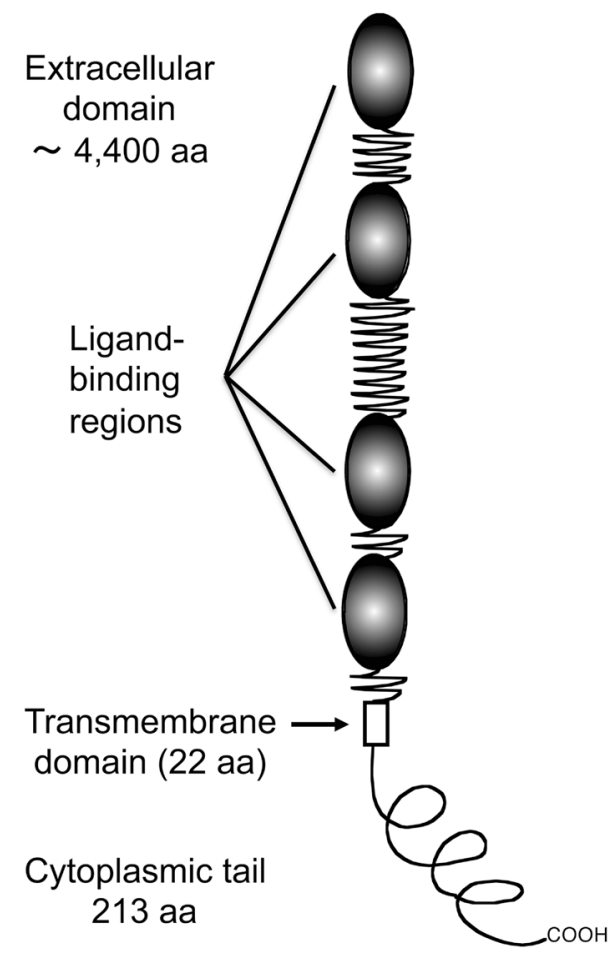

Fig. 1. Schematic diagram of megalin structure. Megalin has four ligand-binding regions in the N-terminus of the extracellular domain, a transmembrane domain, and a short cytoplasmic tail in the $\mathrm{C}$ terminus.

\section{Expression of Megalin}

Megalin is expressed in the apical plasma membrane and located at the endocytic apparatus (including apical coated pits, endosomes, and the dense apical tubules) of epithelial cells (7). Historically, megalin is identified as an antigen of Heymann nephritis, an experimental rat nephritis and model of human membranous nephropathy (8). Therefore, it is well known that megalin reabsorbs the filtered proteins from the glomerulus at the proximal tubules in the kidney. However, megalin is distributed not only in the kidney but also in various other epithelial tissues, such as the choroid plexus ependymal cells, the inner ear, ciliary epithelium, the thyroid gland, parathyroid gland, type II pneumocytes, the small intestine, the placenta, endometrium, oviduct, the yolk sac, and the epididymis (Reviewed in Ref. 1).

After translation, megalin binds with receptor-associated protein (RAP), a high affinity chaperone protein for LDL receptors, in the endoplasmic reticulum (ER) (9-11). RAP protects newly synthesized receptors from the binding of ligands through the protein processing in the ER. If the ligands bind with the receptors in the $\mathrm{ER}$, the receptors can aggregate and be retained. RAP-deficiency decreases the expression of megalin in the kidney proximal tubules (12).

In Dent's disease, which is caused by mutations in the renal
Table 1. Ligands for megalin.

\begin{tabular}{|c|c|c|}
\hline Category & Ligand & $\begin{array}{l}\text { Reference } \\
\text { No. }\end{array}$ \\
\hline \multirow[t]{3}{*}{ Vitamin-binding proteins } & Retinol-binding protein & 15 \\
\hline & Transcobalamin-vitamin B12 & 17 \\
\hline & Vitamin D-binding protein & 16 \\
\hline \multirow[t]{7}{*}{ Other carrier proteins } & Albumin & 31 \\
\hline & Hemoglobin & 32 \\
\hline & Lactoferrin & 33 \\
\hline & Odorant-binding protein & 34 \\
\hline & Sex hormone-binding globulin & 35 \\
\hline & Selenoprotein $\mathrm{P}$ & 36 \\
\hline & Transthyretin & 37 \\
\hline \multirow[t]{4}{*}{ Lipoproteins } & Apolipoprotein B & 38 \\
\hline & Apolipoprotein E & 33 \\
\hline & Apolipoprotein $\mathrm{H}$ & 39 \\
\hline & Apolipoprotein $\mathrm{J} /$ Clusterin & 40 \\
\hline \multirow[t]{5}{*}{ Hormones } & Epidermal growth factor & 41 \\
\hline & Insulin & 41 \\
\hline & Parathyroid hormone & 18 \\
\hline & Prolactin & 41 \\
\hline & Thyroglobulin & 42 \\
\hline \multirow[t]{8}{*}{ Enzymes and inhibitors } & $\beta$-Amylase & 22 \\
\hline & Lipoprotein lipase & 43 \\
\hline & Lysozyme & 41 \\
\hline & $\beta 1-$ Microglobulin & 34 \\
\hline & $\begin{array}{l}\text { Plasminogen activator inhibitor } \\
\quad(\mathrm{PAI})\end{array}$ & 44 \\
\hline & $\begin{array}{l}\text { PAI-tissue-type plasminogen acti- } \\
\text { vator }\end{array}$ & 33 \\
\hline & PAI-urokinase & 45 \\
\hline & Prourokinase & 44 \\
\hline \multirow[t]{4}{*}{ Stress response proteins } & Mesoderm development (MESD) & 46 \\
\hline & $\beta 2$-Microglobulin & 41 \\
\hline & Pancreatitis-associated protein 1 & 34 \\
\hline & Receptor-associated protein & 47 \\
\hline \multirow[t]{5}{*}{ Drugs and chemicals } & Aminoglycosides & 22 \\
\hline & Aprotinin & 22 \\
\hline & Chitosan & 23 \\
\hline & Polymyxin B & 22 \\
\hline & Trichosanthin & 48 \\
\hline
\end{tabular}

chloride channel $\mathrm{ClC}-5$, renal megalin expression is also decreased and this induces defective tubular uptake of filtered proteins and proteinuria (13). This indicates a functional relationship between ClC-5 and endocytosis of megalin.

\section{E. Function of Megalin}

A knockout study of megalin in mice has demonstrated that the mice die perinatally because of respiratory dysfunction with lung expansion as well as abnormally forebrain formation. About 
$2 \%$ of the megalin-deficient mice survive to adulthood and their urine contains a distinguishable pattern of proteins with low molecular weight (14).

Megalin binds with vitamin-binding proteins including retinolbinding protein (RBP), vitamin D-binding protein (DBP), and transcobalamin, which are transport proteins for retinol, vitamin $\mathrm{D}$, and vitamin B12, respectively, in the blood circulation. Megalin incorporates RBP-retinol, DBP-vitamin D, and transcobalamin-vitamin B12 complexes from the glomerular filtrate in the renal proximal tubules to recover valuable substances from the urine (15-17). In addition to this, after the reabsorption of DBP-vitamin D complex, 25$(\mathrm{OH})$ vitamin $\mathrm{D} 3$ is converted through hydroxylation to an activated form, 1,25-(OH $)_{2}$ vitamin $\mathrm{D} 3$, which is involved in $\mathrm{Ca}^{2+}$ homeostasis including the absorption of $\mathrm{Ca}^{2+}$ in the small intestine. In megalin-deficient mice, both forms of vitamin D3 levels are reduced in the blood circulation. The mice exhibit defects of bone formation (16). Megalin is involved not only in vitamin D activation but also in the clearance of parathyroid hormone (PTH) from glomerular filtrate in the kidney and the subsequent lysosomal degradation of PTH (18). PTH removal results in $\mathrm{Ca}^{2+}$-deposition on the bone.

Megalin endocytoses a complex of the zymogen form of matrix metalloprotease 2 (proMMP-2) with a tissue inhibitor of metalloprotease (TIMP)-2 in the kidney (19). MMP-2 is involved in multiple pathways such as the regulation of angiogenesis and metastasis (20). This indicates that megalin plays important roles for regulating MMP-2 activity under pathological conditions.

Megalin also can bind chemicals, such as aminoglycosides, e.g., kanamycin and gentamicin. Aminoglycosides are incorporated into the inner ear and the proximal tubules through megalinmediated endocytosis and are accumulated in the cells, resulting in ototoxicity and nephrotoxicity $(21,22)$. Chitosan, a $\beta 1-4$ linked copolymer of GlcN and GlcNAc, is also known as a ligand for megalin (23). Chitosan/siRNA nanoparticles, which are the complex of polycationic chitosan with polyanionic siRNA, are used for a proximal tubular epithelial cell-targeted gene silencing (24).

\section{F. N-Glycosylation of Megalin}

There are 30 potential $N$-glycosylation sites on the extracellular domain on mouse megalin. Among them, 14 sites are on the ligand-binding regions. A glycan analysis with mass spectrometry revealed that megalin is heterogeneously glycosylated in rat kidney, bears complex-type $N$-glycans in greater abundance than high-mannose type $N$-glycans. The study also demonstrates the existence of core fucosylation and a bisecting GlcNAc residue (25). Another mass spectrometric analysis targeting a specific glycan motif demonstrates that megalin is identified as a Lewis Xconjugated glycoprotein in the mouse kidney. In addition, the study showed that the glycans are detected on the spacer regions, but not on the ligand-binding regions (26). However, until now, little has been known about the glycoforms of megalin.

\section{G. Effects of $\mathbf{N}$-Glycans on Megalin}

It is well known that different tissues have specific glycoforms of glycoproteins. A study using purified megalin from two strains of mouse with or without a kidney-specific core 2 GlcNAc transferase revealed that modification of $O$-glycans affected the ligand-binding activity of megalin (27). Thus, the author and collaborators hypothesized that megalin glycoforms would exist in a body and that $N$-glycans in megalin would modify the ligandbinding activity in each tissue. The study demonstrated that at least two segment-specific glycoforms exist in the proximal tubule of the kidney through histochemical analyses with lectins (Fig. 2) and purification of megalin glycoforms. One glycoform recognized by Lens culinaris agglutinin (LCA) was expressed on the proximal convoluted tubule (PCT) and the other glycoform recognized by wheat germ agglutinin (WGA) was expressed on the proximal straight tubule (PST). In addition, a vitamin-binding protein, RBP, was absorbed selectively in the PCT in vivo and bound with the glycoform purified through LCA affinity chromatography. Bovine albumin was absorbed both in PCT and in PST and bound with both glycoforms (Summarized in Fig. 3). Binding analyses with PNGase F-treated megalin suggested that megalin $N$-glycandependently interacted with RBP, DBP, and albumin(2).

The Lectin Frontier Database, which lists comprehensive data of lectin-standard glycan interactions (28), indicates that LCA and WGA recognize core-fucosylated and hybrid-type $N$-glycans, respectively. Therefore, the RBP binding analysis implied that core-fucosylated $\mathrm{N}$-glycans enhanced the RBP binding activity. Actually, megalin from Fut8 knockout mice, which lack core fucosylation (29), exhibited less RBP binding activity than that from wild-type mice. Additionally, Fut8 knockout mice reabsorbed less endogenous RBP in the kidney than did wild-type mice.

\section{H. Conclusion}

Megalin mediates various physiological functions by incorporating numerous ligands. Megalin is expressed not only in the renal proximal tubules but also in other tissues. The tissues would express tissue-specific megalin glycoforms. A recent study demonstrated that $\mathrm{N}$-glycan modifications altered the ligand-binding activity of megalin (2). A subsequent study revealed that $O$ glycosylation on LDL receptor and related receptors enhanced the ligand interactions (30). Therefore, tissue-specific glycosylations would modify the ligand-binding activity of megalin to internalize the ligands required by each tissue. Further investigation of the 


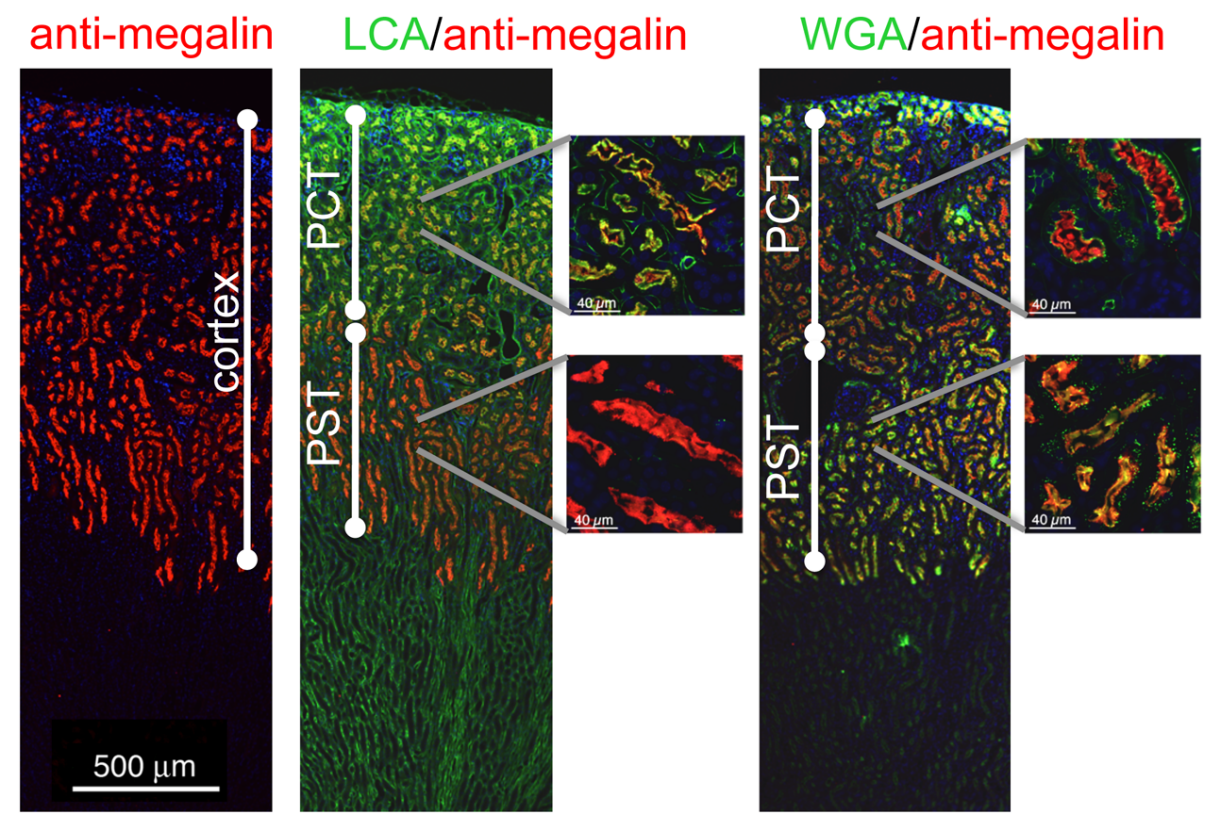

Fig. 2. Distribution of megalin and glycans recognized by Lens culinaris agglutinin (LCA) and by wheat germ agglutinin (WGA) in the mouse kidney. Megalin was expressed in the proximal tubules. LCA and WGA selectively stained the proximal convoluted tubules (PCTs) and the proximal straight tubules (PSTs), respectively.

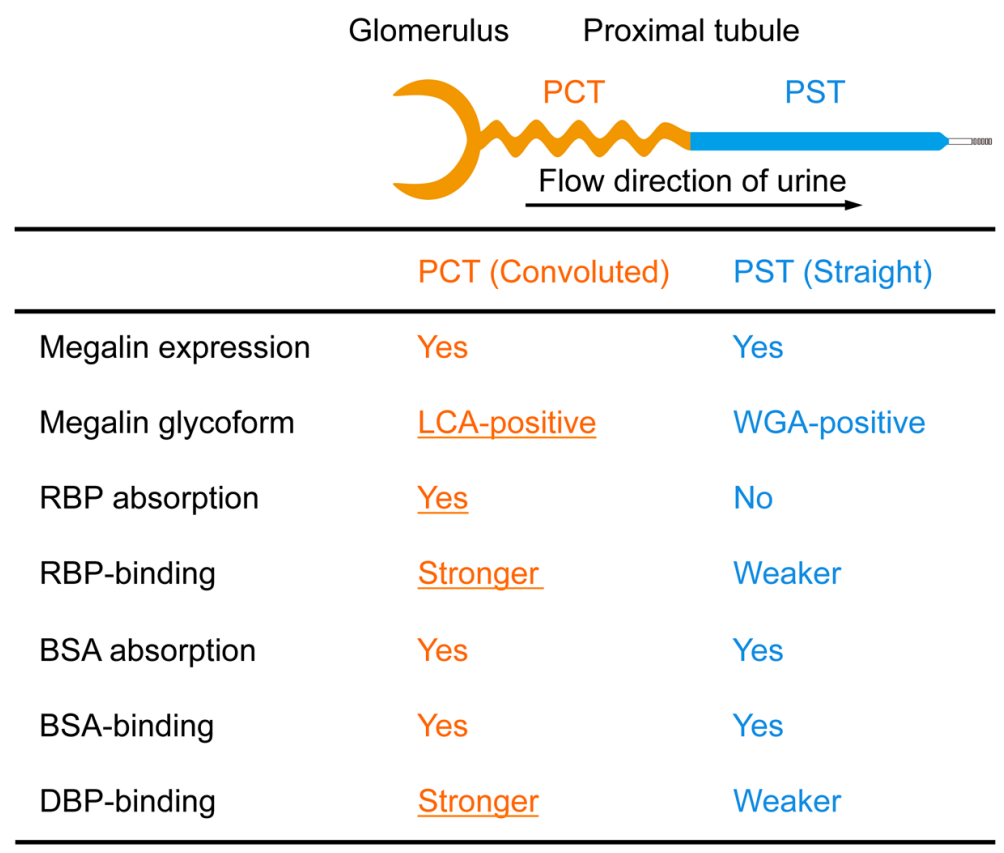

Fig. 3. Summarized expression of megalin glycoforms in the proximal tubule segments and the ligand absorption in vivo with ligandbinding in vitro. Megalin glycoforms recognized by Lens culinaris agglutinin (LCA) and by wheat germ agglutinin (WGA) were expressed on the proximal convoluted tubule (PCT) and the proximal straight tubule (PST), respectively. Retinol-binding protein (RBP) was selectively absorbed in PCTs. LCA-positive megalin glycoform from PCTs bound strongly with RBP. Bovine serum albumin (BSA) was absorbed in both segments and was recognized by both megalin glycoforms. Vitamin D-binding protein (DBP) was selectively recognized by the LCA-positive glycoform.

glycoforms of megalin and their ligand selectivities will clarify the function of megalin in each tissue and our understanding of the molecular mechanism by which megalin binds many ligands with different structures.

\section{Acknowledgments}

This work was supported by a Grant for Scientific Research from Yasuda Women's University (No. 102456). 


\section{References}

1. Christensen, E. I., and Birn, H. (2002) Nat. Rev. Mol. Cell Biol. 3, 258-268.

2. Hirano, M., Totani, K., Fukuda, T., Gu, J., and Suzuki, A. (2017) Biochim. Biophys. Acta 1861(1 Pt A), 3106-3118.

3. Korenberg, J. R., Argraves, K. M., Chen, X. N., Tran, H., Strickland, D. K., and Argraves, W. S. (1994) Genomics 22, 88-93.

4. Saito, A., Pietromonaco, S., Loo, A. K., and Farquhar, M. G. (1994) Proc. Natl. Acad. Sci. U.S.A. 91, 9725-9729.

5. Davis, C. G., Goldstein, J. L., Südhof, T. C., Anderson, R. G., Russell, D. W., and Brown, M. S. (1987) Nature 326, $760-765$.

6. Chen, W. J., Goldstein, J. L., and Brown, M. S. (1990) J. Biol. Chem. 265, 3116-3123.

7. Christensen, E. I., Birn, H., Verroust, P., and Moestrup, S. K. (1998) Int. Rev. Cytol. 180, 237-284.

8. Kerjaschki, D., and Farquhar, M. G. (1982) Proc. Natl. Acad. Sci. U.S.A. 79, 5557-5581.

9. Bu, G., Geuze, H. J., Strous, G. J., and Schwartz, A. L. (1995) EMBO J. 14, 2269-2280.

10. Willnow, T. E., Armstrong, S. A., Hammer, R. E., and Herz, J. (1995) Proc. Natl. Acad. Sci. U.S.A. 92, 4537-4541.

11. Willnow, T. E., Rohlmann, A., Horton, J., Otani, H., Braun, J. R., Hammer, R. E., and Herz, J. (1996) EMBO J. 15, $2632-2639$.

12. Birn, H., Vorum, H., Verroust, P. J., Moestrup, S. K., and Christensen, E. I. (2000) J. Am. Soc. Nephrol. 11, 191-202.

13. Piwon, N., Gunther, W., Schwake, M., Bosl, M. R., and Jentsch, T. J. (2000) Nature 408, 369-373.

14. Willnow, T. E., Hilpert, J., Armstrong, S. A., Rohlmann, A., Hammer, R. E., Burns, D. K., and Herz, J. (1996) Proc. Natl. Acad. Sci. U.S.A. 93, $8460-8464$.

15. Christensen, E. I., Moskaug, J. O., Vorum, H., Jacobsen, C., Gundersen, T. E., Nykjaer, A., Blomhoff, R., Willnow, T. E., and Moestrup, S. K. (1999) J. Am. Soc. Nephrol. 10, 685-695.

16. Nykjaer, A., Dragun, D., Walther, D., Vorum, H., Jacobsen, C., Herz, J., Melsen, F., Christensen, E. I., and Willnow, T. E. (2001) Cell 96, $507-515$.

17. Moestrup, S. K., Birn, H., Fischer, P. B., Petersen, C. M., Verroust, P. J., Sim, R. B., Christensen, E. I., and Nexø, E. (1996) Proc. Natl. Acad. Sci. U.S.A. 93, 8612-8617.

18. Hilpert, J., Nykjaer, A., Jacobsen, C., Wallukat, G., Nielsen, R., Moestrup, S. K., Haller, H., Luft, F. C., Christensen, E. I., and Willnow, T. E. (1999) J. Biol. Chem. 274, 5620-5625.

19. Johanns, M., Lemoine, P., Janssens, V., Grieco, G., Moestrup, S. K., Nielsen, R., Christensen, E. I., Courtoy, P. J., Emonard, H., Marbaix, E., and Henriet, P. (2017) Sci. Rep. 7, 4328.

20. John, A., and Tuszynski, G. (2001) Pathol. Oncol. Res. 7, 14-23.

21. Schmitz, C., Hilpert, J., Jacobsen, C., Boensch, C., Christensen, E. I., Luft, F. C., and Willnow, T. E. (2002) J. Biol. Chem. $277,618-622$.

22. Moestrup, S. K., Cui, S., Vorum, H., Bregengård, C., Bjørn, S. E., Norris, K., Gliemann, J., and Christensen, E. I. (1995) J. Clin. Invest. 96, 14041413.

23. Yuan, Z. X., Zhang, Z. R., Zhu, D., Sun, X., Gong, T., Liu, J., and Luan, C. T. (2009) Mol. Phram. 6, 305-314.

24. Gao, S., Hein, S., Dagnæs-Hansen, F., Weyer, K., Yang, C., Nielsen, R., Christensen, E. I., Fenton, R. A., and Kjems, J. (2014) Theranostics 4, 1039-1051.

25. Morelle, W., Haslam, S. M., Ziak, M., Roth, J., Morris, H. R., and Dell, A. (2000) Glycobiology 10, $295-304$.

26. Hashii, N., Kawasaki, N., Itoh, S., Nakajima, Y., Harazono, A., Kawanishi, T., and Yamaguchi, T. (2009) J. Proteome Res. 8, $3415-3429$.

27. Zhang, H., Yoshioka, S., Miyazaki, M., Kannagi, R., and Suzuki, A. (2008) Biochim. Biophys. Acta 1780, 479-485.

28. Hirabayashi, J., Tateno, H., Shikanai, T., Aoki-Kinoshita, K. F., and Narimatsu, H. (2015) Molecules 20, 951-973.

29. Fukuda, T., Hashimoto, H., Okayasu, N., Kameyama, A., Onogi, H., Nakagawasai, O., Nakazawa, T., Kurosawa, T., Hao, Y., Isaji, T., Tadano, T., Narimatsu, H., Taniguchi, N., and Gu, J. (2011) J. Biol. Chem. 286, 18434-18443.

30. Wang, S., Mao, Y., Narimatsu, Y., Ye, Z., Tian, W., Goth, C. K., Lira-Navarrete, E., Pedersen, N. B., Benito-Vicente, A., Martin, C., Uribe, K. B., Hurtado-Guerrero, R., Christoffersen, C., Seidah, N. G., Nielsen, R., Christensen, E. I., Hansen, L., Bennett, E. P., Vakhrushev, S. Y., Schjoldager, K. T., and Clausen, H. (2018) J. Biol. Chem. 293, 7408-7422.

31. Cui, S., Verroust, P. J., Moestrup, S. K., and Christensen, E. I. (1996) Am. J. Physiol. 271, F900-F907.

32. Gburek, J., Verroust, P. J., Willnow, T. E., Fyfe, J. C., Nowacki, W., Jacobsen, C., Moestrup, S. K., and Christensen, E. I. (2002) J. Am. Soc. Nephrol. 13, 423-430.

33. Willnow, T. E., Goldstein, J. L., Orth, K., Brown, M. S., and Herz, J. (1992) J. Biol. Chem. 267, 26172-26180.

34. Leheste, J. R., Rolinski, B., Vorum, H., Hilpert, J., Nykjaer, A., Jacobsen, C., Aucouturier, P., Moskaug, J. O., Otto, A., Christensen, E. I., and Willnow, T. E. (1999) Am. J. Pathol. 155, 1361-1370.

35. Hammes, A., Andreassen, T. K., Spoelgen, R., Raila, J., Hubner, N., Schulz, H., Metzger, J., Schweigert, F. J., Luppa, P. B., Nykjaer, A., and Willnow, T. E. (2005) Cell 122, 751-762.

36. Olson, G. E., Winfrey, V. P., Hill, K. E., and Burk, R. F. (2008) J. Biol. Chem. 283, 6854-6860.

37. Sousa, M. M., Norden, A. G., Jacobsen, C., Willnow, T. E., Christensen, E. I., Thakker, R. V., Verroust, P. J., Moestrup, S. K., and Saraiva, M. J. (2000) J. Biol. Chem. 275, 38176-38181.

38. Stefansson, S., Chappell, D. A., Argraves, K. M., Strickland, D. K., and Argraves, W. S. (1995) J. Biol. Chem. 270, $19417-19421$.

39. Moestrup, S. K., Schousboe, I., Jacobsen, C., Leheste, J. R., Christensen, E. I., and Willnow, T. E. (1998) J. Clin. Invest. 102 , $902-909$.

40. Kounnas, M. Z., Loukinova, E. B., Stefansson, S., Harmony, J. A., Brewer, B. H., Strickland, D. K., and Argraves, W. S. (1995) J. Biol. Chem. 270, $13070-13075$.

41. Orlando, R. A., Rader, K., Authier, F., Yamazaki, H., Posner, B. I., Bergeron, J. J., and Farquhar, M. G. (1998) J. Am. Soc. Nephrol. 9, $1759-1766$.

42. Zheng, G., Marino, M., Zhao, J., and McCluskey, R. (1998) Endocrinology 139, 1462-1465.

43. Kounnas, M. Z., Chappell, D. A., Strickland, D. K., and Argraves, W. S. (1993) J. Biol. Chem. 268, 14176-14181.

44. Stefansson, S., Kounnas, M. Z., Henkin, J., Mallampalli, R. K., Chappell, D. A., Strickland, D. K., and Argraves, W. S. (1995) J. Cell Sci. 108, 2361-2368.

45. Moestrup, S. K., Nielsen, S., Andreasen, P., Jørgensen, K. E., Nykjaer, A., Røigaard, H., Gliemann, J., and Christensen, E. I. (1993) J. Biol. Chem. 
268, 16564-16570.

46. Lighthouse, J. K., Zhang, L., Hsieh, J. C., Rosenquist, T., and Holdener, B. C. (2011) Dev. Dyn. 240, 577-588.

47. Kounnas, M. Z., Argraves, W. S., and Strickland, D. K. (1993) J. Biol. Chem. 268, 8188-8192.

48. Chan, W. L., Shaw, P. C., Tam, S. C., Jacobsen, C., Gliemann, J., and Nielsen, M. S. (2000) Biochem. Biophys. Res. Commun. 270, $453-457$.

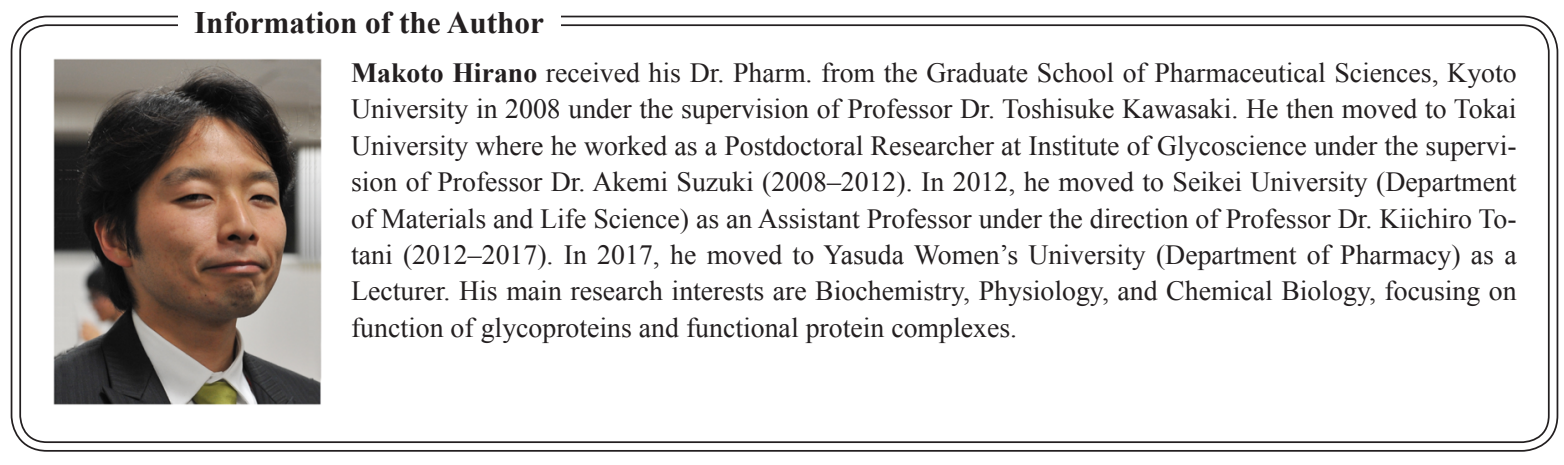

